\title{
Osiemnastowieczny poprzednik reportażu
}

Janusz Maciejewski 


\section{Janusz Maciejewski}

\section{Osiemnastowieczny poprzednik reportażu}

$\mathrm{W}$ śród okolicznościowej literatury politycznej czasów konfederacji radomskiej i barskiej, obok wielu gatunków tradycyjnych - wielokrotnie już wykorzystywanych w tego typu piśmiennictwie - znajdujemy też formy nowe, dotąd niespotykane. Do najoryginalniejszych z nich należą krótkie prozatorskie utwory epickie, doniesienia o jakimś konkretnym, ważnym, szokującym opinię publiczną wydarzeniu. Genetycznie wywodzą się one z prasy, która w tym właśnie okresie zaczęła się bujnie rozwijać, zarówno w postaci drukowanej, jak i gazetek pisanych, przeżywających w trzeciej ćwierci XVIII wieku swe apogeum. W prasie owej, a zwłaszcza w tzw. czasopismach moralnych, popularne były opowieści — o autentycznych bądź zmyślonych - wydarzeniach, które miały być szczytnym albo godnym krytyki przykładem postępowania. O związkach omawianych tu tekstów okolicznościowo-politycznych z ówczesnymi periodykami świadczą chociażby niektóre ich tytuły. Jeden z popularniejszych utworów nazywano - w różnych przekazach - konsekwentnie Monitor lub Monitorium ${ }^{1}$, a więc tak, jak powszechnie wówczas czytywane czasopismo moralne.

W omawianej grupie literatury okolicznościowej czasów radomsko-barskich część jej ma charakter alegoryczny. Czasem - jak we wspomnianym wyżej Monitorium - anonimowy autor stosuje daleko idące uogólnienie, przekształcając utwór w swoistą przypowieść o spotkaniu przez narratora użalających się na niewdzięczność Polaków personifikacji Wiary i Wolności. Kiedy indziej - jak w mającym wiele przekazów Jarmarku ${ }^{2}$ — pod prostą i przejrzystą alegorią opisuje wydarzenia Sejmu Ekstraordynaryjnego 1767/68 jako właśnie targowisko.

' Literatura barska (Antologia), opr. J. Maciejewski, Wrocław 1976 (BN I 108), s. 37-38.

2 Zamieszki sejmu w' Warszautie 1767 będace, pod nazwiskiem Jarmarku opisane, ibid., s. 211-215. 
Tekst, który autorzy opracowania tu publikują, Postępek niegodziwy wojska rosyjskiego $w$ Bie$c z u \ldots$ (w innej wersji Postępek szkaradny...), należy do realistycznej odmiany tej grupy utworów. Mają one największy spośród dotąd przywoływanych związek z gazetkami pisanymi, które także dawały bogate relacje $z$ toczących się walk. W stosunku do nich ma on jednak bardziej rozbudowaną narrację, choć konsekwentnie trzymającą się jednego wydarzenia, a także zalążek fabuły. Dzięki temu zbliża się do wykształconego ponad stulecie później gatunku dziennikarskiego: reportażu. Jest w jakimś stopniu jego poprzednikiem.

Narrator utworu jest dokładnym, skrupulatnym opowiadaczem. Wylicza szczególowo niegodziwości Rosjan, nie pomijając żadnej, ale i bez hierarchi i ich ważności. Zniszczenia dokonane $\mathrm{w}$ kościele są dlań w gruncie rzeczy godniejsze napiętnowania niż gwałty na „pannach i mężatkach”, „duszenie dzieci” wymienia jednym tchem z „rozcinaniem” pierzyn, a oczywiście największe oburzenie wywołuje profanacja hostii świętej. Z perspektywy dzisiejszego czytelnika zyskuje to z jednej strony smak archaiczności, a z drugiej wywołuje pewien - niezgodny $z$ intencjami autora - dystans wobec relacjonowanych wydarzeń (prowadzący do minimalizacji ich znaczenia); opis bowiem czasem wręcz ociera się o komizm. Czyta się tego typu utwory trochę tak, jak współczesne stylizacje na dawne piśmiennictwo, choćby początkowe partie Wariacji pocztowych Kazimierza Brandysa.

Zachowały się do naszych czasów dwie relacje z opisywanego wydarzenia: Postępek niegodziwy wojska rosyjskiego w Bieczu wykonany [die] 5 aprilis $1770 \mathrm{~A}$. (Ossolineum, rkps 567 II, s. 120-122) oraz Postępek szkaradny przez wojsko moskiewskie w mieście grodowym Bieczu [die] 5-go kwietnia 1770 wykonany, a przez tego, który na to patrzyl, opisany (Muzeum Czartoryskich, rkps 865 IV, s. 475-479). Narracja w obu przekazach przebiega według tego samego schematu fabularnego i nawet powtarza niekiedy dokładnie te same zwroty (np. w trzecim zdaniu rękopisu Ossolineum czytamy: „konwent ojców reformatów obtoczyli, na cmentarz drzwi wybili i tam się uszykowali”; w drugim zaś zdaniu rękopisu Czartoryskich jest napisane: „konwent i kościół ojców reformatów obtoczyli, kozacy — na cmentarz drzwi wyciąwszy uszykowani stali”). Przekazy te mają też bardzo zbliżony tytuł i prawie taki sam incipit. Sprawia to, że oba Postępki moglibyśmy w zasadzie uznać za dwie wersje tego samego utworu. Niemniej nie są one identyczne. Relacja druga jest znacznie dłuższa, bogatsza w szczegóły, zawiera także całe fragmenty tekstu nieobecne w pierwszej, np. końcową apostrofę do czytelnika (choć — w mniejszym wymiarze — dzieje się i odwrotnie, np. w drugim zdaniu krótszej wersji znajduje się nieobecna w Postępku szkaradnym... informacja o tym, iż oddział Kierkora po ucieczce „sam ku Gorlicom do obozu udał się”). Dlatego zdecydowaliśmy się przytoczyć niżej oba przekazy w całości.

Jeden i drugi są anonimowe, jak to było w zwyczaju okolicznościowej literatury politycznej tego okresu. W Postępku szkaradnym... wprawdzie w tytule autor nawet ujawnił się jako naoczny świadek opisywanych wydarzeń, ale oczywiście pozostał bezimienny. Można się zastanawiać, czy obie wersje Postępku... napisała ta sama osoba. Wskazywałyby na to wspomniane wyżej podobieństwa między utworami. Można by więc postawić hipotezę, że ten sam autor $\mathrm{w}$ pewnym odstępie czasu napisał najpierw jedną, a następnie drugą wersję, prawdopodobnie dla różnych potencjalnych odbiorców. 
Jest wszakże jedna okoliczność, która przeczyłaby takiej hipotezie. Są to pewne różnice w pisowni mogące świadczy- też o różnicach w wymowie między obu relacjami. Otóż, o ile w Postępku szkaradnym... nazwa miejscowości Biecz zapisywana jest zgodnie z jej oficjalnym brzmieniem, o tyle w Postępku niegodziwym... mamy w większości przypadków zapis Bicz. Ale niekonsekwentnie - trafia się dwa razy wersja Biecz oraz stale jest używany przymiotnik biecki (a nie «bicki). Wskazywałoby to, iż ten, który pisał krótszą wersję, miał skłonność do „pochylonego" wymawiania $E$ w nazwic miasta, lecz zarazem była to wymowa dość chwiejna. W Postępku szkaradnym... nie ma śladu owej chwiejności.

Prawdopodobna byłaby jednak odpowiedź, że po pierwsze, nie musiał rzeczy przepisywać sam autor, ale ktoś inny i to wymowę skryby, nie zaś autora, ujawnia przekaz Biblioteki Ossolineum. Takie rozumowanie broniłoby hipotezy jednego autora. Można też przyjąć, że pisali obie wersje różni ludzie, którzy jednakże korzystali z jakiejś wspólnej podstawy wcześniej przez nich przeczytanej bądź zasłyszanej (stąd przy wspólnym zasadniczym schemacie narracyjnym tak duże rozbieżności w samej tkance słownej). Oczywiście, wszystkie te hipotezy są oparte na bardzo kruchych podstawach i nie zamicrzam tutaj sprawy rozstrzygać. Sygnalizuję tylko istnienie problemu.

Kilka słów natomiast nalcży się jeszcze kwestiom edytorskim. Przygotowując obie wersje Postępku... do druku, autorzy opracowania dokonali w zakresie pisowni zabiegów modernizacyjnych polegających na sprowadzeniu jej do dziś obowiązujących zasad ortograficznych (a więc np. tomżyńskiey zmieniliśmy na tomżyńskiej, nocuiq̨c na nocując itp.) z zachowaniem jednakże cech ówczesnej wymowy (a więc np. nie modernizowaliśmy końcówki emi na ymi, potym na potem, zachowaliśmy formy: wyjachat, przecięż, koncempt czy skazauszy zamiast wskazawszy, nie ujednolicaliśmy grafii w wyrazie naprzód obok najprzód). Wyjątkiem od tej zasady respektowania zapisu właściwości wymowy była zmiana spółgłosek bezdźwięcznych na dźwięczne w wyrazach: batoszkowali, kłótki oraz odwrotnie w formach: zchronili, zttulki, zkatowane, bydź etc. (zgodnie $z$ obecnymi normami zapisu, gdyż wymowa dzisiejsza nie odbiega od ówczesnej).

Problemem przy respektowaniu cech ówczesnej wymowy była jej chwicjność. Sygnalizowałem ją już na przykładzie oboczności Biecz/Bicz. Zdecydowaliśmy się rozwiązać tę sprawę, stawiając w drugim przypadku znak diakrytyczny nad $E\left(E^{\prime}\right)$. Podobnie postąpiliśmy przy oboczności: kaleczyli/kaliczyli, mieszczanie/mieszczani. W przypadku innej chwiejności: niekonsekwentnego występowania $O$ i $O$ w końcówkach dopełniacza oraz celownika liczby mnogiej rzeczowników (np. żón, reformatóm) rozstrzygaliśmy zgodnie z dzisicjszą ortografią. Tak samo zdecydowaliśmy w sytuacji nagminnego w XVIII-wiecznych rękopisach opuszczania znaku diakrytycznego nad $O$, gdy nie sposób było rozstrzygnąć, czy fakt ten wiązał się $z$ ówczesną wymową, czy jedynie grafią.

$Z$ innych decyzji:

- modernizacja zgodnie z obecnymi normami pisowni lącznej lub rozdzielnej wyrazów: Na reszcie, po tym, co raz, zrana oraz form „nie" z czasownikami, np. niechca

- zachowanie ówczesnych form aspektu niedokonanego: wytamowali, wysypowali etc.

— zachowanie pozostałości liczby podwójnej duiema kapłanom 
— usunięcie spółgłosek podwojonych w wyrazach: cella, kommunikant, kommenda, passyja, apparaty etc.

- wprowadzenie grupy -yja/-yjum w zapisie wyrazów zapożyczonych z łaciny, wymawianych dwuzgłoskowo, np. konfederacya, pasya, cyboryum, antepedyum etc.

- poprawienie w Postepku niegodziwym... formy cymboryum na cyboryjum, regimentar na regimentarz oraz zapisu nazwiska Putawski na Putaski, zmieniono także dyftongiczny zapis nosówki przed spółgłoską zwarto-wybuchową w tytule: postempek (potwierdzający wymowę asynchroniczną) na postępek

— zachowanie zastosowanych w Postępku szkaradnym... wyróżnień tekstowych (spacje) oraz wielkich liter w końcowych eksklamacjach oraz zbitce „Wiara — Wolność”, wielkie litery wprowadzono także na początek przytoczeń w cudzysłowach

- normalizacja zapisu wstawek łacińskich, np. Justitia poprawiono na Iustitia, ejusdem na eiusdem

— rozwiązanie skrótów typu: ImcX na Imć ksiądz/książ

— oddanie konwencjonalnego skrótowego zapisu formuły oznaczającej datę jako die ujęte w nawiasy kwadratowe

- modernizacja interpunkcji

Na zakończenie mogę - jako ciekawostkę — dodać, że pierwszą z prezentowanych niżej wersji, a mianowicie, Postępek niegodziwy..., zamierzałem w swoim czasie opublikować w wydanej w 1976 r. antologii Literatury barskiej w dziale Prozy narracyjnej. Niestety cenzura zatrzymała tekst w całości. Aby zasygnalizować uważnym czytelnikom tę interwencję, zostałwiłem wzmiankę o tym utworze we wstępie (s. LXXIII) i to bez przypisu odsylającego do manuskryptu - co czyniłem wyłącznie w przypadku utworów publikowanych w antologii. Niekonsekwencję tę - ku mojej radości - cenzor przeoczył. Takie były zabawy w one lata. 
Postępek niegodziwy wojska rosyjskiego w Bieczu wykonany [die] 5 aprilis $1770 \mathrm{~A}$.

(Rkps Ossol. 567 II s. 120-122)

Oprac. Janusz Maciejewski i Magdalena Rudkowska

Gdy J. W. Kierkor regimentar[z] w pięćdziesiąt koni wyjechał przeciw Moskwie i napadł na liczne wojska moskiewskie zbliżające się ku Biéczu, nazad rejterował się. W tej rejteradzie utracił ludzi dziesięciu. Sam ku Gorlicom do obozu udał się. Tu kozacy moskiewscy całe miasto i konwent ojców reformatów obtoczyli, na cmentarz drzwi wybili i tam się uszykowali, z tych jedni drzwi do kościoła wyłamowali, drudzy do okien kościelnych i konwentu strzelali i dobywszy się do kościoła, a potym wpadłszy przez kościól do konwentu, tam zakonników z cel wywłóczyli, bili i kaleczyli, do skarbcu otwierać sobie kazali. A gdy takowym postępkiem przymusili wspomnionych ojców otworzyć zakrystyją i skarbiec, tam najprzód sepety i depozyta szlacheckie potłukli i zabrali, pieniądze miedzane wysypowali, zbierać reformatom kazali, a gdy nie chcieli, bili, tłukli i mordowali. Przy tych depozytach zabrali ojcom reformatom alby kościelne i obrusy, baldachim obdarli, namiot z cyboryjum wzięli i wiele innych rzeczy kościelnych pozabiérali.

Potym wpadłszy do miasta najprzód kościoły rabowali, a gdy do fary udali się, tam drzwi wybili, z cyboryjum Przenajświçtszy Sakrament na ziemię wyrzucili, puszkę wzięli, komunikant na drzwiach kościelnych przylepili, groby pootwierali, trupów z trumien powyrzucali, skrzynie, skrzynki kościelne i ludzkie porąbali, karbony potłukli, świece, pasyjki jedne pozabierali, drugie potłukli i miejsce w miejsce splądrowali. Potym drzwi do zakrystii kamieniem $^{3}$ wybili, tam wpadłszy kielichy wszystkie i pateny zabrali, szafy kościelne porąbali. Aparaty prawie jak wszystkie, alby, obrusy, korporały, olea sacra, piksidim do chorych, ampułki srebrne zabrali. Drugie aparaty antepedyja poobdzierali, et praecipue kapę litą bogatą szacunku aureor[um] numm[orum]. 10 ad minimum wzięli. Sukno nawet czerwone z gradusów i ołtarza, kobierce i inne rzeczy, których wyrazić niepodobna, zrabowali i z wszelkicj ozdoby kościół farny biecki ogołocili.

Drugi kościół Świętego Ducha, szpitalny w Bieczu, tak zrabowali, że strzępka najmniejszego nie zostawili. Monstrancyją połomali, puszkę, kielichy, wota i wszystko funditus zabrali. Depozyta tamże znajdujące się szlacheckie i miejskie poodbijali i wzięli. Ubóstwo szpitalne pobili i co mieli, nawet i płaszcze z nich pobrali i gwałty w szpitalu robili.

Trzeci kościół Świętego Piotra odbili i co lepsze rzeczy pobrali, karbony poodbijali, otworem zostawili.

Akta grodzkie i miejskie w Bieczu podarli, porąbali i powyrzucali, a drugie przedawali. Privilegia authentica pozabierạli i drzwi do nich poodbijali. Miasto całe funditus zrabowali, panny i mężatki publicznic bez wstydu gwałcili, który rabunek i gwałt trwał przez cały dzień i noc po całym mieście i przedmieściu. Na probostwo farne bieckie gdy wpadli, tam Imci

\footnotetext{
${ }^{3}$ W rękopisie wyraz ten był dwukrotnie powtórzony (,Potym drzwi kamieniem do zakrystyji kamieniem wybili"). Niewątpliwy lapsus calami.
} 
księdza proboszcza i oficyjała tudzież i sześciu księży zastali, najprzód ludzi kańczugami cięli, potym samego Imci księdza oficyjała i księży jego bili, spisami kłuli, szablami płazowali, z pistoletów strzelać i zabić chcieli, kaleczyli — zgoła, co może być słów i okrucieńsw, to nad Imci księdzem oficyjałem i księżą jego dokazowali. Było tego więcej niż trzy godziny. Jedni bili, a drudzy rabowali, ci wyszli, a drudzy i trzeci przyszli - a co raz okrutniejsi. Samych batogów jedni księża po sto, drudzy po dwieście wzięli, głowy, ręce im pokaleczyli. Każdy się krwią oblał. Gdy tak całe probostwo zrabowali, drzwi do pokojów wybili, kłódki wszędzie poodcinali, sepety i szkatuły potłukli. Zrabowali, co im się podobało, a co jedni zostawili, to drudzy i trzeci przyszedłszy rabowali. Księżom wikaryjuszom funditus wszystko zabrali i okna powycinali. To tylko, co na sobie mieli, zostało. Gdy po tym rabunku przyszedł na probostwo pułkownik i inni oficyjerowie, a Imć ksiądz proboszcz i oficyjał żalił się o takowy postępek przed niemi. Na to odpowiedzieli: „Gdzie potyczka, tam i rabunek”. A gdy rzekł, że się duchownych bić i kaleczyć nie godziło, na portret J. O. księcia biskupa krakowskiego skazawszy odpowiedział: „Na tego narzekajcie”. Potym, gdy jeden kapłan wymówił, że to nie sztuka bezbronnych zabijać i kaleczyć, jeden z nich dobył palasza i rzekł: „Ot — pałasz, tnij się ze mną". I innych wielce podobnych było dyskursów, a bardziej żartów i pożałowania moskiewskiego.

Poszli potym na kwatery, a Imć ksiądz proboszcz i oficyjał biecki udal się do kościoła, który zastawszy zrabowany, gdy przyszedł przed cyboryjum i zobaczył Sanctissmum wyrzucone, pozbierał z rewerencyją i w korporale lokował na ołtarzu, lampy po kościele rozświecić kazał, a potym sam pobiegł do komendy uskarżając się tak wielkiej wzgardy samemu Chrystusowi Panu uczynioncj. Ale warta puścić nie chciała i flintą odpędziła, uderzywszy po dwakroć tegoż prałata, który łzami się zalawszy, odszedł do siebie. A Moskale porwawszy się przede dniem o godzinie czwarej z Biécza do Gorlic - i na tym się cała rzecz w Biéczu skończyła, której praktyki podobna a condito tego miasta ${ }^{4}$ takowej lub podobnej nie było. I Bóg zdeptany i kościoły złupione i księża zbici i panny pogwałcone. Szlachta i mieszczanié wszyscy ogołoceni i z ostatniej prawie koszule odarci, zbici, pokaleczeni i postrzelani zostali, wszystko co mieli utracili, jedni się porozchodzili, a drudzy na żebraninę się udali, nie mając sposobu do życia.

\footnotetext{
^ Dwa ostatnie wyrazy w rękopisie zostały — najwyraźniej błędnie — dwukrotnie zapisane (,podobna tego miasta a condito tego miasta").
} 


\section{Postępek szkaradny przez wojsko moskiewskie w mieście grodowym Bieczu [die] 5-go kwietnia 1770 wykonany, a przez tego, który na to patrzyt, opisany}

(Rkps Czart. 865 IV s. 475-479)

Oprac. Janusz Maciejewski i Magdalena Rudkowska

Imć Pan Kierkor regimentarz J. W. Pułaskiego marszałka konfederacyji ziemi łomżyńskiej, nocując z komendą w Bieczu, wyjachał w sto koni tylko przeciw Moskwie za miasto, pod Siepietnicę [die] piątego kwietnia o godzinie siódmej z rana, lecz postrzegłszy znaczną liczbę Moskwy do dwóch tysięcy ludzi wynoszącą, co prędzej rejterował się, za którym kozaki skoczywszy piętnastu konfederatów zabili, reszta się ucieczką salwowała. Po tej robocie udała się Moskwa do rabunku, a naprzód konwent i kościół ojców reformatów obtoczyli, kozacy - na cmentarz drzwi wyciąwszy - uszykowani stali, inni do kościoła, dwoje drzwi wystawiwszy, wpadli, stamtąd do cel drzwi wybijali, zakonników z nich wywłóczyli, bili, tłukli, kaleczyli, rąbać, strzelać, kłuć chcieli, aby im pieniądze wydali, drudzy na cmentarzu do okien kościelnych i klasztornych strzelali. Tak okrutnym więc uciśnieniem przymuszeni ojcowie otworzyć zakrystyją i skarbiec, tam wpadłszy kufry poodbijali, pieniądze i depozyta szlacheckie pozabierali i przy nich wiele kościelnych rzeczy, a osobliwie alb solennych, baldachim obdarli, groszaki miedzane z worków po ambitach wysypowali, i reformatom zbierać kazali, a gdy nie chcieli, niemiłosiernie ich batożkowali. Z całego zgromadzenia trzech tylko zakonników wolnych było od bicia, którzy się schronili, nawet i chorym pardonu nie dali, groby nawet otwierać sobie kazali, w refektarzu kufle i talerze potłukli, samę nawet od dobrodziejów wyżebraną zabrali eleemozynę, a gdy już nienasycona złość więcej brać nie miała, okna nareszcie powystrzelać doradziła. I tak ojców ogołociwszy, udali się do miasta i kościoła szpitalnego Świętego Ducha, jedni rabowali kościól, w którym Najświętszy Sakrament z cyboryjum wyrzucili, puszkę, monstracyją, kielichy wszystkie, wota, ornaty, kapy, alby, firanki i wszelkie mobilija kościelne do ostatniego platka wyrabowali. Sepety i skrzynie miejskie w schowaniu tam będące potłukli; z nich suknie, pieniądze, perły, sreberka nic nie zostawiwszy, zabrali. Inni miasto i mieszczan rabowali, bili, kaleczyli, odzierali, okna wycinali, panny i mężatki gwałcili, dzieci dusili, pościeli rozcinali i pierze na wiatr wysypowali; słowem: domu i miejsca żadnego nie było, ktorego by nie splądrowali i nie spustoszyli. Obywatele więc patrzący na sromotne żon i córek swoich zgwałcenie, obdarci, skłuci, zranieni, jedni krwawemi prawie zalewający się łzami dla żywienia skatowanego ciała z miasta powychodzili; drudzy zbyt stłuczeni i pomordowani nigdzie pójść nie mogący u własnych sąsiadów dla wyżebrania kawałka chleba, z dostatnich ostatni żebracy, ręku nadstawiali.

Ciągnie dalej osnowę dzikiej zajadłości złość heretycka tym sposobem: szturmują do kościoła farnego dragoni i dobywszy drzwi, naprzód Najświętszy Sakrament z cyboryjum wyrzucili, puszkę wzięli, a na większą hańbę Wiary Świętej (O Boże! Jakżeś cierpliwy!) komunikant na drzwiach kościelnych przylepili, lampy przecięż srebrnej i sukienek na obrazach podobno nie postrzegli. Potym obrazy wszystkie z ołtarzów pozdzierali. Mensy i gradusy drewniane porujnowali; skrzynie, sepety, skrzynki cechowe i karbony kościelne połupali i z nich wszystko pozabierali; groby wszystkie pootwierawszy zszukali. Pasyje i pa- 
syjki jedne pobrali, drugie powywracali. Nareszcie do zakrystyji żelazne drzwi długim kamieniem z gadusów ołtarzowych wziętym wybili, wszystkie kielichy, pateny, krzyż srebrny, kapę bogatą sto złotych kosztującą, ornaty lepsze, alby, firanki, obrusy piękniejsze i co im się tylko podobało zabrali; do skarbcu zaś jednego dobyć się nie mogąc, przecięż w całósi zostawili.

Kozacy na probostwo wpadłszy, naprzód ludzi Imci księdza oficyjała zbiwszy i pokaléczywszy, rozegnali, potym samego Imci księdza oficyjała i księży trzech jego nieprzestannie biczowali, pałaszami płazowali, inni, do pistoletów się porywając i kurki odwodząc, zabiciem odgrażali. Kluczami kościelnemi Imci księdza oficyjała tyrańsko do zranienia po głowie stłukli i spisami kłuć chcieli, jakoż dwiema kapłanom, jednemu rękę, drugiemu bok przebili, samego Imci księdza oficyjała szkaradnie w głowę skaléczyli i więcej nad sto razy prócz płazów batożkowali po plecach i byliby go podobna zabili, gdyby drudzy kapłani, na to okrucieństwo patrząc, nie bronili, na ostatek tak skatowany ucieczką się salwował, ale innym kapłanom toż samo się dostało, nawet znajdujących się tam dla słuchania spowiedzi ojców reformatów równie batożkami cięli, policzkowali, płazowali, strzelać i ścinać chcieli i co może być wzgardy i okrucieństwa, wszystko to duchowieństwu bezbożnicy wyrządzali z taką zawziętością, że jedno zmordowawszy się wychodzili, a drudzy następowali i tak coraz $z$ większą zajadłością do trzeciego razu chodzili na przemiany. Trwał ten obrzydły postępek prawie przez trzy godziny, przez które całe bili, rabowali, troje drzwi do pokojów oficyjalskich na trzaski porąbali, szkatułki, sepety, skrzynki potłukli, z nich pieniądze i bieliznę wszystkę pozabicrali. Cukry, korzenia jedli, wysypowali, dywany i inne kościelne rzeczy poszarpali, papicry także kościclne potargali; ludziom służącym barwy pozabierali, konie z stajni wyprowadzili i na nich zaraz powsiadali. Skóble, kłódki do sklepów, piwnic i szpiklerza poodcinawszy, co tam zastali, brali, pili i rozsypowali. Szkody w samym tylko probostwie (kościoła nic nie tykając) uczynili na złotych 12000.

Ichmościów księży wikaryjuszów podobnież do szczętu zrabowali, tyle tylko zostawując, co na sobie mieli, do tego jeszcze i okna powycinali. Do kościoła świętej Barbary drzwi wybili, tam wszystko splądrowawszy, a nic nic znalazłszy, na koncempt bożka jakiegoś przystroiwszy, na ołtarzu go postawili i odeszli. Poszli potym do kościoła świętego Piotra na górę za miasto, tam drzwi dwoje do zakrystyji wycięli, aparaty lepsze pozabierali, karbony poodbijali, i kościól otworem zostawiwszy, wynieśli się.

Szlachtę mieszkającą na przedmieściu i samych przedmieszczanów rabowali, gwałcili. Folwark proboszczowski wyprzątnęli, rzeczy służącym pobrali. Strzeszyn, wieś do starostwa należącą bieckiego, zrabowali.

Gdy po skończonym rabunku pułkownicy i oficyjerowie moskiewscy (z których jeden miał być Zieliński, drugi Grabowski, obydwa Polacy dysydenci) na probostwo się poschodzili, jeść i pić sobie dać rozkazali. Imć ksiądz proboszcz i oficyjał biecki żalił się przed niemi o tak niesłychane gwałty. Spytał więc jeden: „Czyli ich Waszmość Pan poznasz?”. Odpowiedział: „Poznam, bo mi się dobrze dali we znaki”. Pułkownik na to: „Gdzie jest potyczka, tam musi być i rabunek" i skazawszy na portret J. O. księcia Imci Soltyka biskupa krakowskiego (który jako prawy biskup i senator świątobliwie i gorliwie broniąc Wiary i Wolności w mo- 
skiewskiej zostaje niewoli) powiedział: „Na tego narzekajcie”. Gdy mu potym jeden z duchownych mówił, że nie jest wielka sztuka bezbronnych zabijać i kaleczyć, on dobywszy pałasza dawał mu go w ręce mówiąc: „Oto masz pałasz, tnij się ze mną”, co potym w żart obrócono, a co się komu dostało, to przepadło.

Poszli potym oficyjerowie (którzy sami kalwini byli) na kwatery, a Imć ksiądz oficyjał do kościola, gdzie postrzegłszy cyboryjum wyłupane i Przenajświętszy Sakrament wyrzucony, z wielką rewerencyją pozbierał i do cyboryjum w korporale włożył i zamknął, potym lampy po kościele pozapalać kazawszy nieco zabawił; a gdy snem zmożony do domu powrócił, znowu wściekłość heretycka do kościoła wpadła, wielki ołtarz porujnowała, lichtarze, świece, pasyje potłukła, obrusy, antepedyjum i oponę porozdzierała, a gdy przede dniem dała się złość widzieć, poszedł Imć ksiądz oficyjał do komendy z uskarżeniem sią, ale go warta zamiast puszczenia flintami przywitała.

O godzinie czwartej z rana ten obrzydły, bezbożny i wściekły lud wymaszerował z Biecza i [die] dziewiątego eiusdem stanął w Gorlicach, gdzie nie zastawszy już obozu konfederackiego, kościół i miasto całe zrabowali. Byli i w Kobylance, tam dwór przetrząśli i o kościele myśleli, lecz będący tam cudowny Pa n J e z u s tak im rozum pomieszał i oczy zaćmił, że o kościół się pilnie dopytując, po cmentarzu jeździli, a do niego trafić nie mogli.

Który to czytasz, ktożkolwiek jesteś, cożkolwiek masz ludzkiego w sobie, zdumij się i przypatrz dobrze, czyli najmniejszą w tej wyuzdanej w Północy na łonie najdrapieżniejszych bestyji wychowanej hałastrze ludzkości iskierkę zoczyć możesz? Zadrżyj od żalu Święta Cnoto, a zobacz, jeżeli ta obrzydła trzoda w oczach przynajmniej cokolwiek mieć może Twojego! zalej się krwawemi łzami strapiona Ojczyzno, że jeszcze przed skonaniem Twoim dzika wściekłość rozcina i targa Twoje wnętrzności! Drętwij od strachu dobry katoliku, widząc tak szkaradną Najświętszych Tajemnic obelgę, a gdy nie możesz krwią i życiem własnym ich zasłonić, nadgradzaj przynajmniej najgłębszym z najmocniejszą wiarą uszanowaniem! Ty zaś tak srodze istotnie jak od Żydów niegdyś zhańbiony, wzgardzony, wyszydzony i powtórnic piekielnemi odszczepieńców rękami przybity na drzwiach J e z u, spuść ogniste pioruny na pożarcie powtórnych krzyżowników Twoich, aby kiedy wierzyć nie chcą, uznali moc Twoję w zgubie swojej! Pereat Mundus, fiat Iustitia. 